\title{
Kirjallisuutta
}

\section{AIKUISKASVATTAJILLE TÄRKEÄ KIRJA OPPIMISESTA JA OPISKELUSTA}

Marton, F. Dahlgren, L.O. Svensson. L. Själö. $R$. Oppimisen ohjaaminen. Espoo. Weilin + Göös. 1980.

Ihmisen psyykkiset toiminnot on psykologiassa perinteisesti jaettu tieto-, tunne- ja tahtotoimintoihin. Tietotoimintojen, kognition tutkimus onkin pitkät perinteet omaava psykologisen tutkimuksen haara. Kognitiiviseksi psykologiaksi kutsutaan kuitenkin myös tiettyä psykologian teoreettista suuntausta, jolle on ominaista ihmisen tarkasteleminen tiedonkäsittelijänä, tietoa aktiivisesti hankkivana sitä muokkaavana ja toimintaansa tiedon avulla ohjaavana olentona (von Wright 1980 ja 1981). Tämä aiemmin vallinnutta behavioristista selitysmallia kritisoiva ajattelutapa saavutti 1970-luvun alussa oppimisen tutkimuksessa niin nopeasti keskeisen aseman, että on puhuttu alalla tapahtuneesta "'kognitiivisesta käänteestä'. Meillä kognitiivista oppimisen teoriaa ovat edustaneet lähinnä professorit Johan von Wright ja YrjöPaavo Häyrynen. Vaikka suuntaus on tärkeä juuri opetuksen ja kasvatuksen kannalta, ei sillä ole toistaiseksi ollut merkittävää jalansijaa maamme kasvatustieteen laitoksilla.

Tähän mennessä kognitiivisesta oppimisen teoriasta on suomen kielellä ollut saatavissa varsin vähän tietoa. Siksi on hyvin ilahduttavaa, että pohjoismaiden tunnetuimman suuntausta edustavan tutkimusryhmän työtä esittelevä kirja on saatu suomeksi. Toivottavasti pian saadaan suomeksi myös sellaiset kognitiivisen oppimisen teorian perusteokset kuin J.S. Brunerin 1960 ilmestynyt The Process of Education (kasvatus- prosessi), 1966 ilmestynyt Towards a Theory of Instruction (kohti opetuksen teoriaa) ja D.P. Ausubelin teoriaa esittelevistä kirjoista esim. 1977 ilmestynyt J.A. Novakin kirja Theory of Education (kasvatuksen teoria).

Martonin tutkijaryhmä lukeutuu oppimisen tutkimuksessa ns. realistiseen suuntaukseen. Sen edustajat pyrkivät tutkimaan todellisen elämän kannalta olennaisia oppimistapahtumia luonnonmukaisissa olosuhteissa. Yksi nykyihmisen kannalta tärkeimmistä oppimistapahtumista on koulu- ja yliopistoopiskelu. Suuntauksen edustajat katsovat, ettei opiskeluun voida soveltaa merkityksettömän aineiston oppimisesta laboratoriokokeissa saatuja tuloksia. Niiden avulla ei opiskelun tehostamisen ongelmia voida ratkaista. Opiskelussa on aina kysymys merkityksellisen aineiston oppimisesta. Opiskelijan on kyettävä saamaan "'puhuttuun tai kirjoitettuun kieleen perustuvan esityksen perusteella selville jotain oikean todellisuuden ilmiöistä'. Ymmärtäminen on tärkeämpää kuin pelkkä muistaminen.

Realismin voidaan nähdä liittyvän suuntauksen teoreettisiin lähtökohtiin myös toisella tavalla. Se ilmenee tavassa, jolla tutkijat määrittelevät oppimisen. Se on heidän mukaansa yksilön toimintaa, joka muuttaa tämän käsityksiä ympäristön tapahtumista ja ilmiöistä. Kirjan suomennokselle annettu harhaanjohtava nimi "'Oppimisen ohjaaminen', ei tuo tätä Martonin ryhmän peruslähtökohtaa esiin niin kuin alkuperäinen nimi "'Inlärning och omvärldsuppfattning"', oppiminen ja maailmankuva). Voidaan siis aina kysyä, mikä on oppimisen myötä syntyvien käsitysten sisältö, miten oikeita ja re- alistisia käsityksiä opetuksen ja oppimisen tuloksena syntyy.

Kirjan keskeisimpiä ajatuksia voidaan kuvata oheisen kaavion avulla. Tarkastelun lähtökohtana on oppimisen tutkimusta - ja paljolti myös kouluopetusta - pitkään hallinneen tiedon ja oppimisen luonnetta koskevan käsityksen kritiikki. Tälle, kirjoittajien määrälliseksi kutsumalle oppimisnäkemykselle on ominaista huomion kiinnittäminen ensisijassa siihen, miten suuren määrän opetetuista yksittäisistä tiedoista oppilas kykenee myöhemmin palauttamaan mieleensä. Sen sijaan se ei kiinnitä huomiota siihen, millaisia laadullisia eroja muistamisessa esiintyy: miten kielellisessä muodossa välitetty tieto on ymmärretty ja muistetaanko esitetystä ajatuksen ydin vai vain esityksen irrallisia yksityiskohtia.

Kirjoittajien tutkimukset osoittavat, ettei muistaminen ole mekaanista esitetyn toistamista. Mieleen ei myöhemmin palaudu ensisijassa erillisiä yksityiskohtia, vaan tietty kokonaishahmo: kertomuksen juoni, esitetty väite ja sen perustelut tai tietty käsitys jostain asiasta. Muistamisen kannalta on siksi ratkaisevaa, miten henkilö on tulkinnut oppiaineksen sisällön ja miten tietoisesti tuo kokonaishahmo on syntynyt. Yksityiskohtienkin muistaminen riippuu merkittävästi siitä, miten ne liittyvät oppilaan tekstistä muodostamaan tulkintaan. Yksityiskohdat, joilla ei ole tulkinnassa olennaista merkitystä; unohdetaan helpoimmin. Tietoisesti muodostettu käsitys oppisisällön kokonaisrakenteesta säilyy muistissa muuttumattomampana kuin heikosti tiedostettu kokonaishahmo. Toisaalta oppilas saattaa esittää oppiaineiston sisältämän ajatuksen luovan 
Kaavio 1. Opiskelijan suuntautumisen vaikutus oppimistulokseen

\begin{tabular}{|c|c|c|}
\hline $\begin{array}{l}\text { KÄSITYS TIEDON } \\
\text { A OPPIMISEN }\end{array}$ & $\begin{array}{l}\text { SUUNTAUTUMI- } \\
\text { NEN OPISKELUSSA }\end{array}$ & OPPIMISTULOS \\
\hline
\end{tabular}

LUONTEESTA

\begin{tabular}{|c|c|c|c|}
\hline $\begin{array}{l}\text { Määrällinen } \\
\text { Oppiminen on eril- } \\
\text { listen tietojen } \\
\text { muistamista, } \\
\text { kykyä toistaa } \\
\text { esitetty }\end{array}$ & $\begin{array}{l}\text { Pintasuuntautuminen } \\
\text { Huomion suuntaami- } \\
\text { nen esitykseen ja sii- } \\
\text { hen sisältyviin yksityis- } \\
\text { kohtiin }\end{array}$ & $\begin{array}{l}\text { "Atomistista tietoa" } \\
\text { Nopeasti unohtuvia } \\
\text { erillisiä yksittäis- } \\
\text { tietoja }\end{array}$ & $\begin{array}{l}\text { Ajattelutapa ei } \\
\text { muutu } \\
\text { Opiskelun } \\
\text { kriisi }\end{array}$ \\
\hline$\sqrt{2}-$ & 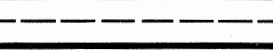 & - & 一一禾 \\
\hline $\begin{array}{l}\text { Laadullinen } \\
\text { Oppiminen on } \\
\text { todellisuutta, } \\
\text { joitain ilmiöitä } \\
\text { koskevien käsitys- } \\
\text { ten syventämistä } \\
\text { ja tarkentumista }\end{array}$ & $\begin{array}{l}\text { Syväsuuntautuminen } \\
\text { Huomion suuntaami- } \\
\text { nen esityksen ajatus- } \\
\text { sisältöön ja } \\
\text { loogiseen rakentee- } \\
\text { seen (mistä puhutaan, } \\
\text { mitä sanotaan, millä } \\
\text { perustellaan) }\end{array}$ & $\begin{array}{l}\text { "Holistista tietoa" } \\
\text { Asian ymmärtämistä } \\
\text { ja sijoittamista } \\
\text { yhteyksiinsä, } \\
\text { tiedon kokonais- } \\
\text { rakenteen hahmot- } \\
\text { tamista. } \\
\text { Pysyviä, toimintaan } \\
\text { vaikuttavia ajattelu- } \\
\text { tapoja }\end{array}$ & $\begin{array}{l}\text { Ajattelutapa } \\
\text { muuttuu } \\
\text { Tapahtuu älyl- } \\
\text { listä kehitystä }\end{array}$ \\
\hline
\end{tabular}

mielikuvituksensa ja muun tietonsa avulla uudella, omaperäisellä tavalla, vaikka hän ei alkuperäisen esityksen yksityiskohtia muistaisikaan.

Erot muistisuoritusten laadussa perustuvat siis siihen, että eri henkilöt ymmärtävät esitetyt ajatukset eri asteisesti. Ymmärtämisen erot eivät kirjoittajien mukaan kuitenkaan perustu ensisijassa älykkyyden tai tarkkaavaisuuden asteen eroihin, vaan siihen, millä tavalla oppilaat pyrkivät oppisisällön oppimaan, mihin he suuntaavat huomionsa sitä opiskellessaan. Osa tutkimuksissa mukana olleista opiskelijoista keskittyi opiskelussaan selvästi painamaan mieleensä opiskeltavan tekstin sellaisenaan. Toiset taas pyrkivät analysoimaan tekstin ajatussisältöä ja selvittämään itselleen, mistä kirjoittaja puhuu, mitä hän asiasta sanoo ja millä hän sanomaansa perustelee. Edellistä suuntautumistyyppiä tutkijat kutsuvat pintasuuntautumiseksi. Sille on tyypillistä huomion kiinnittäminen ilmaisuun ilmaistavan asian sijasta. Jälkimmäistä, käsiteltävään asiaan keskittyvää suuntautumistyyppiä kirjoittajat kutsuvat syväsuuntautumiseksi.
Pintasuuntautumisesta on tuloksena se, että oppisisällöstä muistetaan erillisiä yksityiskohtia, mutta tekstin punainen lanka ja looginen rakenne jää omaksumatta. Syväsuuntautumisen tuloksena on oppiaineksen sisältämien todellisuutta koskevien väitteiden ja kirjoittajan ajatuksen ymmärtäminen, mikä näyttää johtavan myös yksityiskohtien parempaan muistamiseen. "Syväsuuntautumisen" onkin useissa tutkimuksissa osoitettu olevan merkittävä opinnoissa menestymisen ennustajana.

Opiskelijoiden erilaiseen suuntautumiseen johtavia syitä ei kirjassa käsitellä systemaattisesti. Kirjoittajat näyttävät kuitenkin pitävän oppilaan aiempia oppimiskokemuksia sekä opiskelutehtävään ja -tilanteeseen liittyviä tekijöitä tärkeimpinä suuntautumisen määrääjinä. Pintasuuntautuminen voi olla seurausta voimakkaasta suoriutumisen paineesta taikka opetuksesta, joka suuntaa huomion esim. koekysymysten avulla ymmärtämisen sijasta yksittäisten tietojen muistamiseen. Syväsuuntautuminen ei kirjassa selostettujen kokeiden valossa näytä syntyvän yhtä helposti kuin pintasuuntautuminen. Kuitenkin laajojen asiakokonaisuuksien hallintaa edellyttävät opiskelutehtävät saattavat johtaa pintasuuntautuneen opiskelijan kriisiin, josta on seurauksena uudenlainen suhtautuminen tietoon ja opiskeluun.

Määrällisen ja laadullisen oppimiskäsityksen erittely johtaa kirjoittajat arvioimaan oppimisen ja kehityksen välisiä eroja uudelleen aikuiskasvatuksen kannalta mielenkiintoisella tavalla. Määrälliseen oppimiskäsitykseen on liittynyt oppimisen ja kehityksen jyrkkä erottaminen toisistaan. On katsottu, että ajattelutavan laadullinen kehitys tapahtuu nuoruusiässä. Sen jälkeen tapahtuisi vain tietojen määrän kasvua. Kirjoittajat osoittavat kuitenkin, että oppiminen johtaa myös ajattelutavan laadullisiin muutoksiin ja älylliseen kehitykseen. Kehitys ei siis ole vain nuoruusvuosiin rajoittuva ilmiö.

Oppimisen ohjaaminen -teosta voisi ehkä luonnehtia suurelle yleisälle tarkoitetuksi kasvatuspykologiseksi kirjaksi. Kirjoittajat esittävät siinä ajattelutapansa ja tärkeimmät teoreettiset ideansa käyttäen 
suorittamiaan tutkimuksia havainto- ja esimerkkiaineistona. He eivät pyri sen enempää teoreettisten käsitteidensä täsmälliseen määrittelyyn kuin tutkimustensa seikkaperäiseen kuvaamiseenkaan. Monien olennaisten kysymysten käsittely jääkin kirjassa esimerkkien ja yleisluontoisten viittausten varaan. Tietty keskustelunomaisuus leimaa myös kirjan esitystapaa: se on kiinnostava ja mukaansatempaava, mutta samalla löyhä ja samoja asioita tarpeettomasti toistava.

Kirjaa ei ole tarkoitettu kognitiivisen oppimisen tutkimuksen yleisesittelyksi. Silti se avaa näköaloja moniin oppimisen ja opetuksen tutkimuksen ajankohtaisiin ongelmiin ja tuo esiin useita kognitiiviselle oppimisen tutkimukselle tyypillisiä teemoja. Toisaalta eräiden olennaisten kysymysten käsittely jää kirjassa ongelman toteamisen tasolle, vaikka näihin ongelmiin olisi kognitiivisen teorian perusteella jo kyetty antamaan merkittäviä vastauksiakin. Varsin avoimeksi jäävät kysymykset oppimisen laajan siirtovaikutuksen edellytyksistä ja siitä, miten opetuksessa voitaisiin edistää "'syväoppimista",

Martonin ryhmä toteaa kirjassaan, että ",opetuksen niin kuin oppimisenkin tarkoitus on antaa tietoja jostakin oikeastaan itse opetuksen ulkopuolella olevasta’. Tähän päästään, jos oppilas todella ymmärtää sisällön, jos hän kykenee ',kaivamaan esiin', esimerkeistä ja opettajan esittämistä kuvauksista yleispätevän tiedon ja jos hän saa tilaisuuden myös käyttää tietoa. Sen sijaan kirjassa ei pohdita, millaiset oppisisällöt ovat "'yleispäteviä',. Siinä ei käsitellä opitun laajan siirtovaikutuksen aikaansaamisen kannalta ratkaisevan tärkeätä kysymystä yleistysten ja käsitteiden muodostumisesta opetuksessa eikä tehdä eroa yhtäältä selittävien, teoreettisten yleistysten ja toisaalta luokittelevien, arkihavaintoon pe- rustuvien yleistysten välillä. Kuitenkin juuri selittävät teoreettiset yleistykset ovat ensisijassa sitä yleispätevää oppisisältöä, jonka omaksuminen voi johtaa opitun vaikutuksen siirtymiseen myös sellaisten ongelmien ratkaisemiseen, joita opetustilanteessa ei ole käsitelty.

Kirjan näkökulma on tutkimuksen lähtökohtien mukaisesti opiskelua ja opiskelutekniikkaa painottava. Päähuomio kiinnitetään siihen, miten opiskelija selvittää itselleen opiskeltavan tekstin keskeisen ajatussisällön. Sen sijaan kirjassa ei juuri pohdita millaisia oppimisen kannalta olennaisia eroja oppimateriaalien välillä voi olla ja miten oppimateriaalin laadinnassa ja opetuksessa voitaisiin helpottaa keskeisen sisällön ymmärtämistä. Kokemus kuitenkin osoittaa, että myös oppikirjojen kirjoittajat saattavat suhteessaan opetettaviin asioihin edustaa sekä "'pintasuuntautumista"' että "'syväsuuntautumista", ts. esittää ilmiöistä joko pinnallisia havaintoja tai olennaisia syy- ja seuraussuhteita. Asiaakin sisältävät tekstit voivat esitystavallaan joko helpottaa omaksumista tai tehdä keskeisen sisällön hahmottamisen oppilaalle perin vaikeaksi. Martonin ryhmä ei tee oppimisteoriastaan sanottavasti opetusta koskevia päätelmiä. Kuitenkin juuri opetuksen ja oppiaineksen jäsentämisen . kysymyksissä kognitiivinen oppimisteoria on johtanut sekä kaikkein merkittävimpiin käytännön sovellutuksiin. Oppiaineksen sisäisen logiikan ja avainkäsitteiden välisten yhteyksien selvittämisen ei nimittäin tarvitse jäädä vain opiskelijan spontaanin jäsentämistyön varaan. Opettaja voi olennaisella tavalla edistää kokonaiskäsityksen muodostumista ja asian ymmärtämistä orientoimalla oppilaat hyvin käsiteltävään asia-alueeseen ja tuomalla heti opiskelun alussa esiin asian ymmärtämisen kannalta keskeiset periaatteet.
Oppimisen ohjaaminen esittää tärkeän ja ajankohtaisen vaihtoehdon suomalaista aikuiskasvatusta pitkään hallinneelle koulutusteknologiselle ja behavioristiselle kasvatusajattelulle. Vaikka kirjassa tarkastellaan ennen muuta opiskeluun liittyviä kysymyksiä, on siinä esitetty ymmärtämisen laatua korostava näkökulma tärkeä myös kaikille, jotka suunnittelevat ja toteuttavat opetusta. Kirjaa voi suositella varauksetta kaikille aikuiskasvatuksen eri sektoreilla toimiville kasvattajille ja kouluttajille. Toivottavasti kirja omalta osaltaan valmistelee tutkimuksessa jo tapahtuneen kognitiivisen käänteen toteutumista myös aikuiskasvatustyön käytännössä.

\section{Lähteet:}

von Wright, Johan. 1980. Kognitiivisen psykologian kehityksen piirteitä.

Psykologia 2/1980.

von Wright, Johan. 1981. Kognitiiviset prosessit ja kasvatustieteellinen tutkimus. Kasvatus $1 / 1981$.

Jaakko Virkkunen 